Canadian University Music Review

Revue de musique des universités canadiennes

\title{
Backyard World/Canadian Culture: Looking at Festival Agendas
}

\section{Pauline Greenhill}

Volume 19, numéro 2, 1999

Canadian Perspectives in Ethnomusicology

Perspectives canadiennes en ethnomusicologie

URI : https://id.erudit.org/iderudit/1014445ar

DOI : https://doi.org/10.7202/1014445ar

Aller au sommaire du numéro

\section{Éditeur(s)}

Canadian University Music Society / Société de musique des universités canadiennes

\section{ISSN}

0710-0353 (imprimé)

2291-2436 (numérique)

Découvrir la revue

Citer cet article

Greenhill, P. (1999). Backyard World/Canadian Culture: Looking at Festival Agendas. Canadian University Music Review / Revue de musique des universités canadiennes, 19(2), 37-46. https://doi.org/10.7202/1014445ar

\section{Résumé de l'article}

Festivals enact agendas that are at times hegemonic, and at other times resistant. The Winnipeg Folk Festival and Folklorama, though otherwise disparate, have common concerns with both ethnicity and music but their multiculturalisms are fundamentally, structurally different. Folklorama reduces difference to make it palatable to mainstream culture; diversity gives way to standardization and sameness. In contrast, the Winnipeg Folk Festival, within circumscribed limits, opens a space for divergent expression. Folklorama is accessible financially, spatially, and temporally to people with a range of incomes. The Winnipeg Folk Festival requires more time and financial resources of its audiences.
All Rights Reserved @ Canadian University Music Society / Société de musique des universités canadiennes, 1999
Ce document est protégé par la loi sur le droit d'auteur. L'utilisation des services d'Érudit (y compris la reproduction) est assujettie à sa politique d'utilisation que vous pouvez consulter en ligne.

https://apropos.erudit.org/fr/usagers/politique-dutilisation/ 


\title{
BACKYARD WORLD/CANADIAN CULTURE: LOOKING AT FESTIVAL AGENDAS
}

\section{Pauline Greenhill}

\begin{abstract}
“A World of Music in Your Own Backyard!" (Winnipeg Folk Festival promotion, 1996)
\end{abstract}

“Canada's Cultural Celebration/Le Festival des cultures du Canada” (Folklorama promotion, 1996)

Festivals, such as those referenced in the epigraphs prefacing this paper, enact individual and group agendas that are at times hegemonic, and at other times resistant. My research, ${ }^{1}$ "Cultural Politics and Identity Politics in Festival Construction and Performance," examines how governmental, touristic media, and other agencies use terms like "multiculturalism," "culture," "ethnicity," "pluralism," "folklore," "tradition," and "identity" to communicate powerful, but often rather different, messages. Specifically, I consider how the ideas behind these words are used to encourage or discourage interaction between groups or individuals with ideological differences, or similar relationships vis-à-vis power, politics, gender, sexuality, race, ethnicity, and the state. Whose agendas are foregrounded and whose are backgrounded, and under what circumstances?

"Cultural politics" and "identity politics" are sometimes referred to disparagingly. Cultural politics can be seen as the cynical betrayal of a group's distinctiveness, addressing superficial aspects of outward expression while ignoring deeper meanings; identity politics can be little more than a label which reduces all of a person's salient qualities to one category such as sex, gender, race, class, sexual orientation, and so on. However, I use these terms here, instead, to draw attention to the strategic uses of opportunities for creating culture and identity.

I take as exemplars here two events in Winnipeg, the Winnipeg Folk Festival and Folklorama, which I have been observing and researching with various degrees of concentration, particularly over the past six years. Both events could be termed "multicultural," as their promotional statements quoted above indicate, although Folklorama uses the word more extensively than the Folk

1 I would like to acknowledge the research assistants whose work has been integral to my understanding of specific festivals, and of festivals in general, Danielle Carignan Svenne, Janet Macaulay, Cynthia Thoroski, and particularly Lisa Hagen-Smith, for her incisive comments on this paper. This research has been funded by the Social Sciences and Humanities Research Council of Canada. 
Festival. Though otherwise somewhat disparate, they have common concerns (latent to blatant) with both ethnicity and music. They are also associated with considerable economic as well as cultural power, and they are events to which I, professionally, have rather different relationships.

The executive director of Folklorama has declined to cooperate with me, ostensibly because they felt it would involve too much work, but possibly because they are aware that I have been a strong supporter of a group called Queer Culture Canada, which-among other activities-presented the satirical, parodic "Multi-Culti-Queer Pavilion" during Folklorama in the summer of 1992. ${ }^{2}$ My studies of Folklorama, then, have so far been restricted to examining its public manifestations, such as brochures, media representations, and performances. ${ }^{3}$ My view, then, is skewed towards Folklorama's most commodified and least emergent aspects. It would likely be that in discussion with participants-volunteers, board members, audience, and so on-researchers would locate unalienated experiences of this festival, experiences that are potentially ethically proscribed. ${ }^{4}$

In contrast, my research team did obtain permission to work with the Winnipeg Folk Festival, and has endeavoured to maintain a good relationship with them throughout, including giving the Executive Director/Artistic Director, Pierre Guérin, an opportunity to comment upon (and eventually to make alterations in) our writings about the event. ${ }^{5}$ The Folk Festival has placed few restrictions on our work activities, and none so far on our access to information.

In comparing the Folk Festival with Folklorama, specifically, the 1996 editions of each, I want to show that the multiculturalisms they enact are fundamentally, structurally different. It will be clear that my personal preference is for the Folk Festival's style. I will close by addressing the question of whether it is reasonable to expect festivals to be agents of change, particularly when my own position as an academic seems to offer so much more potential for such action.

\section{FOLKLORAMA: “MCMULTICULTURALISM"?}

Folklorama, held for about two weeks every August since 1970, combines local boosterism with big corporate sponsorship to create a tourist event. Various

2My research on the Multi-Culti-Queer Pavilion, and its successor, the Festival du Voyeur, was discussed in my SSHRCC research proposal, which I made available to the executive director. See also "Can You See the Difference? Queerying the Nation, Ethnicity, Festival, and Culture in Winnipeg," presented by the author at the "Queer Nation?" conference, York University, Toronto, 1997.

3 See Cynthia Thoroski, "Adventures in Ethnicity: Consuming Performances of Cultural Identity in Winnipeg's Folklorama," paper presented to the Folklore Studies Association of Canada/Canadian Women's Studies/Association for Canadian Studies meetings, Learned Societies, St. John's, Newfoundland (1997).

4 In the summer of 1997, however, we successfully approached several individual pavilion organizers, and we worked in close co-operation with them over the final two years of research.

5See Pauline Greenhill, "Finding a Place for Research at the Winnipeg Folk Festival," The Canadian Folk Music Bulletin 29, no. 3 (1995): 14-16; Janet Macaulay, "Stop the Folkin' Music! How I (Kinda) Found My Place at Winnipeg Folk Festival Camping,"ibid., 21-23; Danielle Carignan Svenne, "La Cuisine/Art: Knowing My Place as a Volunteer at the Winnipeg Folk Festival," ibid., 19-21; and Lisa Hagen-Smith, "On Your Mark ... The Audience Place at the Winnipeg Folk Festival," ibid., 16-19. 
"pavilions," located at different venues throughout the city-mainly in ethnic society halls, community centres, and public education buildings-represent ethnic, linguistic, national, and/or geographical groupings. This festival, which in the words of its own promotion "takes you down the street and around the world," is billed in easy superlatives as "Canada's greatest cultural celebration," and "the world's largest multicultural festival."

Ethnic, linguistic, national, and/or geographical groups are represented in one or, in many cases, two "pavilions"-such as the "Pearl of the Orient Philippine Pavilion" and "Philippine Pavilion-Nayong Pilipino," or the "Ireland/Irish Pavilion" and "Isle of the Shamrock-Ireland Pavilion." Only the Centre culturel franco-manitobain hosted more than one pavilion in 1996. One might suspect that the presence of two pavilions indicates some political discord, or even heterogeneity in cultural presentation. But, similarities and differences within and between groups are presented in discrete, separate locations, preventing actual encounters between different perspectives.

Furthermore, Folklorama is structured in such a way as to ensure that contrasts within and between groups are masked by common presentation of three elements: music/dance, food/drink, and the display and sale of crafts. Thus, expressions are limited, even though their Web site suggests that "Folklorama gives every group a chance to release whatever they want to express to everyone about their culture." In actuality, all groups are circumscribed within the aforementioned common structure of musical performances, edibles, and crafts.

To give Folklorama its due, it is remarkably successful at representing the extent to which geographic and national "there" is actually "here," and ethnic and cultural "other" truly part of the "self." That is, neither the performance locations nor the performers are set apart from local communities. Unlike the Winnipeg Folk Festival held in Birds Hill Park, forty kilometres from the city's centre, Folklorama's venues are actually within the boundaries of the city of Winnipeg. Indeed, three 1996 pavilions were within a couple of blocks of my own downtown residence. From pavilion to pavilion, musical performers seem equally drawn from home countries ("Back by popular demand from Paraguay is the acclaimed, internationally renowned harpist Ramon Romero"), from other areas of North America ("Chicago's Polonia choir and dance group will perform on stage;" "Celebrate with Toronto's Greek Folk Dancing Group"), and from the local context ("Experience the sound of Winnipeg's famous Hinode Taiko drumming group").

One of the modes through which this construction of what I call proximate distance has been accomplished in previous years (although it was suspended in 1996, reportedly because it was too expensive) has been the use of a "passport," which is stamped upon entry at every pavilion visited. Just as actual political discord within and between groups is troped in terms of benign variation in entertainment modes and styles through Folklorama's common pavilion structure, border control is troped in the "passport" as a touristic enterprise of movement-if not free, at least inexpensive-rather than one of political power regulation. "Ambassadors" and "Youth Ambassadors" (one 
male and one female) who host each pavilion extend the diplomatic/touristic metaphor. ${ }^{6}$ Their miniaturizing and localizing rhetoric suggests that "at Folklorama you can go around the whole world without leaving the city. Each building with a pavilion in it is like a country!" However, one cannot help noticing cracks in the veneer. For example, the Serbian and Croatian pavilions, only blocks apart, are scheduled in different weeks, as are the Israeli and German pavilions. Indeed, actual engagement with even the most benign of cultural differences is limited.

Some pavilions include audience participation in musical activities: for example, the German pavilion invites attendees to "sing along and dance beneath the big top outdoor tent"; in the Serbian pavilion, one can "join in the famous Kolo dance" and at the Greek Islands pavilion "participate in a Zorba the Greek dance lesson"; both Philippine pavilions advertise karaoke. However, the public's place is always limited. Visitors are hustled in and out of the pavilions for shows presented at standard times, thereby containing their experiences of encounter in time and space.

Folklorama's professed specificity is somewhat belied by its boast that their "exhilarating entertainment is so impressive and internationally renown [sic] that artistic scouts from Walt Disney World have visited the festival regularly to book local talent for Epcot Centre performances." Here Folklorama epitomizes what I call "McMulticulturalism," a term which could be applied to events which, like Folklorama, serve to mask difference as entertaining multicultural display. Indeed, as I have described, Folklorama's praxis-touristic orientation, pavilion formats, merging of international and local acts, prescribed audience roles-promotes similarity (usually that of a hegemonic order), just as McDonald's superficially different layout and decor from restaurant to restaurant never really fails to conceal a stunning uniformity of service and product. When Folklorama collaborates with Disney, a multibillion dollar corporation which, like McDonald's, is well known for exploiting its poorly paid labourers, and which tries to trope work as fun, the comparison seems even more apposite. We could also note that Folklorama relies upon a reported 20,000 volunteer workers who may, at times, perceive their own situation as exploited.

And like McDonald's, Folklorama is a marketing success, bringing much needed tourist dollars to Winnipeg's sagging economy. In this area, it makes a significant contribution. Indeed, its promotional material highlights, for example, the fact that the American Bus Association named Folklorama the number one event in Canada, and a top ten Super Event in North America. But its texts also suggest that it "showcase[s] the diverse cultural heritage of the people who settled in Manitoba and Canada," and here is where the rhetoric of diversity and "cultural odyssey" breaks down.

I am not suggesting that Folklorama should be staging conflict between linguistic/national/ethnic/geographical groups, nor that it can effect actual

6Though these positions replace the anachronistic, less democratic "Princesses" and "Kings" of earlier years, they retain the (inter)nationalist trope. 
diplomacy among them. However, it is clear that Folklorama's implicit, enacted definition of cultural diversity is limited in an exclusive practice that avoids controversy. The definition of diversity does not, for example, acknowledge the possibility of a Queer Nation, as incidents in 1992 revealed. The unofficial, 1992 "Multi-Culti-Queer Pavilion," held at the artist-run Plug In Gallery, like the festival ("Faux-klorama") it parodied, showcased the three structural elements: queer food/drink (cheezies, freshly squeezed orange juice, and fruit loops and homo milk), performance (such as one literally "phoned-in" from Toronto by performance artists Shawna Dempsey and Lorri Millan), and crafts (from exhibitions of "totally queer hair-dos" to sales of T-shirts quoting queer theorist Eve Kosofsky Sedgwick).

Folklorama's response to the Multi-Culti-Queer Pavilion indicated not only homophobia, but a distinct lack of humour about their own activities. The local papers reported that a Folklorama spokesperson said "We just asked them not to use our name in connection with their event. The flavor of the event has no bearing on it,"7 and asserted that the problem was "simply a trademark issue." But their Portage and Main, mainstream lawyers' demands for "the identity of the manufacturer and of the shop or party which (or who) embossed the wording on the T-shirts,"8 for a permanent injunction against Queer Culture Canada using the Folklorama name, and for the recovery and accounting for all the T-shirts, suggests a rather intense concern.

Queer Culture Canada representatives reported to me that they were told they could simply have applied, with other groups, to be an official pavilion. However, when they asked for an application for 1993, the following year, they were told that the form was being redesigned. Interestingly, they never received one. ${ }^{9}$

\section{The WinNiPEg FolK FeSTIVAL: BENETTON MULTICULTURALISM?}

Whereas in everyday life-and at McDonald's and Folklorama-controversy over social and cultural differences may be actively hidden or subdued, at other events, they can be celebrated openly. At the Winnipeg Folk Festival, for example, mainly middle-class white audiences can watch either African and Latino performers or ones who share their own background; lesbian singers can advance radical viewpoints in workshops while Loudon Wainwright can mainstage heterosexism. The term "Benetton multiculturalism" has been widely used by scholars to describe a commodified purveying in media of plural cultures, often in contexts clearly intended to produce shock, surprise, and dissonance. I use the label here for the following reason: the fact that equal time and space is allotted to various musics and perspectives creates some space in a colonial/heterosexist political economy for subalterns, but makes no alterations in power dynamics beyond its own frame. ${ }^{10}$

7“Pavilion Decides to Drop Name," Winnipeg Sun, 2 August 1992.

8Letter, Wilder, Wilder, and Langtry to Cherniak Allen, Barristers \& Solicitors, 4 September 1992.

9 It has also been reported to me that there was an initiative from the deaf community to hold a pavilion at Folklorama. My research team was unable to locate further information.

10See David Theo Goldberg, "Introduction: Multicultural Conditions," in Multiculturalism: A 
The Winnipeg Folk Festival is only slightly younger than Folklorama; 1996 was its twenty-third year. The advertised "world of music in your own backyard" applies loosely, since the Folk Festival is held (in mid-July) in Birds Hill Provincial Park, around forty kilometres from the city centre. Its status as a tourist attraction is indicated by a perusal of the parking lot, where license plates from other provinces, but even more often from the United States, are common. The executive and artistic director, Pierre Guérin, told me that almost a third of the audience is American. Many Folk Festival visitors come back year after year, and many return to a home-away-from-home in the Festival Camping area.

The Festival's musical ideology is resolutely pluralist. In both 1995 and 1996, publicity represented the Folk Festival in terms of world music. Like Folklorama, this included both local and international musicians. In 1996, their categories for music, as advertised in the Folk Festival brochure, were Brittany, Blues, Women in Celtic Music, World Music, Singer-Songwriters, In the Tradition, and On the Edge. Note that these categories are not necessarily mutually exclusive. Artistic Director Guérin says:

There's about a dozen different constituencies being dealt with and those are the places where I have to start ... Usually what ends up happening is that I start with some preconceived notions. I want music from India. I want music from Africa ... And then by the time it comes down to May, I realize that this hasn't happened and something else emerges that happened without my even realizing that it was there. It does take on a life of its own sometimes. ${ }^{11}$

In creating this mix, the Festival at times works against any expectation that it provide a controlled, standardized, comfortably secure product of the sort that Folklorama purveys. In booking performers, Guérin avoids a star system that would, of necessity, favour the Anglo-American mainstream and present his audiences with easily identified, recognizable products:

We try to make a representative selection in terms of styles, genres, approaches ... Two years ago we removed the performers' names entirely from the poster ... to basically send out as a message ... "Don't worry. We pick good music. We have for 23 years. Don't worry about that part. What you have to think about is that this is a fairly unique context that you can experience."

Indeed, arguably the biggest act in 1996 was Punjabi by Nature, which was listed in the brochure as "On the Edge," but which could equally have been placed in "World Music" or "In the Tradition." Guérin comments:

I can think of Natalie McMaster two years ago ... Literally nobody knew who she was. She goes out on that [main]stage and after three songs everybody's

Critical Reader, ed. David Theo Goldberg (London: Blackwell, 1994).

11 Pierre Guérin, interview by the author, 1995, Winnipeg, tape recording (PG95:21-24). This and other quotations are from tapes currently in my own collection. 
enthralled and people are still talking about it two years later ... That's amazing to be able to program an event that way and sort of buck the system.

Despite Guérin's self-effacement, such programming decisions can be decidedly revolutionary. The Folk Festival is set up in a way that counterposes, rather than separates, cultural differences. There are four mainstage evenings (Thursday to Sunday) and three days of workshops (Friday to Sunday). This means that musics and performances not suitable for large concert presentations can find a venue; indeed, not all Folk Festival performers get a mainstage gig. Presentation modes for music juxtapose solitudes with collective activities. There are individual morning or afternoon concerts at workshop stages; there are also workshops which position very different musics under a single rubric. And the mainstage concerts can be seen as a series of sequential individual/group presentations, or as whole choreographed events.

The mainstage evenings, for example, often oblige audiences to deal sequentially with highly contrasted musical sources and aesthetics-from The Nields, to Steve Riley and the Mamou Playboys, to Punjabi by Nature. It is, of course, possible to walk away from, talk during, sleep through, or otherwise ignore music to which one does not want to attend. But the possibility for a synthesis is available, at the audience's pleasure. Artistic Director Guérin commented on

the receptivity of the audience ... If you build an evening and you go from something that's fairly raucous to something that's totally quiet and introspective you take a risk. It can work, and it can not work. Most of the time it does. And you can feel the audience out there working as opposed to just sitting there saying "OK, come on, entertain me, and make it snappy" ... It takes on a life of its own and becomes so much more than anything you could have imagined.

This is particularly true at the Sunday evening finale, which is intended to bring a variety of performers together with the audience in song. Though what they actually sing - "Wild Mountain Thyme," "The Mary Ellen Carter," "Hard Times," and "Amazing Grace"-represents and appeals to white, Euro-American sensibilities, the festival's final invocation is to collectivity, and to a rapprochement between diverse performers and their implicitly diverse audiences.

Similarly, workshops put individual musicians and groups together under common rubrics such as instrument ("Mother Earth's Heartbeat [Percussion Jam]") or place ("Yes, But It's a Dry Cold!!! [Manitoba Songwriters]"). Or they can throw individuals and groups together in serious ways ("Singing Our Way Into the New Millenium") or more lighthearted ones ("My Dog Ate My Database ... or Was It the Other Way Around [Life in the Late '90s]"). Indeed, the connections can be quite arbitrary, as in the recurring alphabet series (e.g., "S is for Shetland's Young Heritage; Sisa Pacari"). Workshops can turn into mini-concerts, without interaction or conversation-musical or otherwisebetween performers, but they can also be sources for novel personal and musical combinations and discourses. Just as each audience member quite literally composes her own "festival" by selecting workshops, those who 
present workshops can compose different sorts of experiences for themselves within that structure.

I would venture to suggest that such a level of lack of control would be Folklorama's worst nightmare; yet it seems to be one desideratum of Folk Festival organizers. At the 1995 press launch, Guérin concluded:

Why do we do it? Well there's a thousand of us [staff and volunteers]; there must be a million reasons, but I believe there's one that we have in common. Because when we go up there, we create a community. We have an opportunity to make a difference. We take a small part of the world and for a short period of time, we make it better.

This outlook contrasts, again, with Folklorama's more passive representational ethos.

But this is not to suggest that the Folk Festival succeeds in all areas. For example, in 1996, although at least one group, The Wyrd Sisters, and several individual singer-songwriters would have represented "womyn's music"often a code word for the presentation of lesbian perspectives-this descriptor did not appear in Folk Festival advertising. "Women in Celtic Music" seems to have taken the symbolic gendered space, though it did not address the space of sexuality. The 1996 Program Book did not include women's music as a category; The Wyrd Sisters, for example, are listed as "Singer/Songwriters."

While the "Benetton multiculturalism" presented by the Folk Festival (and, I would suggest, also understood by its audiences), purveys subaltern cultures as "a profitable means of commodification," 12 such ideas do clearly create some kind of space in a colonial political economy for the subaltern. ${ }^{13}$ Ethnomusicologists have debated for some time the value of world music in colonial contexts; is it the flavour of the month, an opening of aesthetic possibilities, or perhaps some combination of the two? Events like the Winnipeg Folk Festival allow a meeting, and even, at times, a dialogue between different kinds of musics, but too often, the impact, critical or otherwise, is limited to its circumscription in festival time and space.

\section{ACADEME: INDIFFERENCE?}

Some might argue that what I have called "McMulticulturalism" is preferable to imposed monoculture. Perhaps it is, but what concerns me about Folklorama and other events like it is its easy ability to reduce difference; to make it palatable as an adjunct to, or even a creation of, mainstream culture. The experience of diversity becomes one of standardization and sameness. In contrast, the Winnipeg Folk Festival does not require all its performers, volunteers, or audiences to follow identifiable, prescribed routes. Although still within circumscribed limits, as in the 1997 security clampdown on audience nudity, the Winnipeg Folk Festival opens a space for divergent expres-

12Goldberg, "Introduction: Multicultural Conditions," 8.

13 As pointed out by Michelle Wallace in "The Search for the 'Good Enough' Mammy: Multiculturalism, Popular Culture, and Psychoanalysis," in Multiculturalism: A Critical Reader, 259-68. 
sion. The juxtapositions in its Benetton multiculturalism are there to create a viable commercial product, but they can sometimes do so by presenting confrontations, which are the stuff of relationships between the marginalized and the centralized. Note, however, that McDonald's and Benetton's are highly class-inflected locations, and so are their multicultural counterparts. Folklorama is accessible financially and spatially to people with a range of incomes. It is scheduled so that day workers can readily incorporate it into their schedules. The Winnipeg Folk Festival requires more time and more financial resources of its audiences.

Festivals can and sometimes do represent alternatives to hegemony, to monoculture, to McDonald's and Disney, but they do so in a very limited context. Frankly, as an academic, I find it much easier to criticize than to project alternatives. Contrary to popular belief, the academic time and space is in operation all year round, not limited to a few days or a few weeks in the summer, as are Folklorama and the Folk Festival. The academic location can be simultaneously critical and acquiescent. Academics like myself can criticize festivals as discursive locations which fail their own radical potential, but less often do we apply those insights to our own social locations.

Any delusions of grandeur we may have about the possibilities of ethnography as a utopian solution to marginalization and power dynamics should be laid to rest quickly. Even my introductory anthropology course back in the early 1970 s clearly pointed to the manifest dangers of colonial intervention, even by the best intentioned, by what was then called applied anthropology. The moral of that lesson was that though anthropologists used to impose their solutions upon what they perceived as cultural problems, we now know better than to do so.

Current postmodern sophisticates have been taught to recognize that we cannot avoid intervention, which is always, anyway, inevitable; that we have constructed our subjects in our own terms. But this recognition has, if anything, marred our track record in supporting marginalized groups. Antonia Mills's sad chronicle of the reception of ethnographic testimony in a British Columbia aboriginal land claim case ${ }^{14}$ should be required reading for anthropologists, ethnomusicologists, or folklorists who want to understand how our work can be appropriated, commodified, and represented in ways quite contrary to our disciplines' often revolutionary histories.

In the context of research, avoiding assertions of certainty and rightness seems the only safe course. But safety should not be the only desideratum. It is privilege that makes activism less attractive than voyeurism; we give up more in trying to enact change and failing than we do in simply empiricizing the world. Mills could have buried her failure rather than writing a book about it. There are lessons I can take from festivals into my own academic work, particularly: do not impose invariant structures; be open to plural presentations

14 Antonia Mills, Eagle Down Is Our Law: Witsuwit'en Law, Feasts, and Land Claims (Vancouver: University of British Columbia Press, 1994). 
and audiences; and perhaps also, like Pierre Guérin, continue striving to get it right the next time. What I can give back is less clear.

\section{Abstract}

Festivals enact agendas that are at times hegemonic, and at other times resistant. The Winnipeg Folk Festival and Folklorama, though otherwise disparate, have common concerns with both ethnicity and music but their multiculturalisms are fundamentally, structurally different. Folklorama reduces difference to make it palatable to mainstream culture; diversity gives way to standardization and sameness. In contrast, the Winnipeg Folk Festival, within circumscribed limits, opens a space for divergent expression. Folklorama is accessible financially, spatially, and temporally to people with a range of incomes. The Winnipeg Folk Festival requires more time and financial resources of its audiences. 